\title{
Microbial Food Safety Risks Associated with Fresh and Thawed Catfish Fillets during Refrigerated Storage
}

\author{
Thao T. H. Nguyen, Achyut Adhikari*, Debanjana Bhattacharya, \\ Vijay S. Chhetri, Karuna Kharel
}

School of Nutrition and Food Sciences, Louisiana State University Agricultural Center, Baton Rouge, LA, USA

Email: *acadhikari@agcenter.lsu.edu

How to cite this paper: Nguyen, T.T.H., Adhikari, A., Bhattacharya, D., Chhetri, V.S. and Kharel, K. (2018) Microbial Food Safety Risks Associated with Fresh and Thawed Catfish Fillets during Refrigerated Storage. Food and Nutrition Sciences, 9, 1261-1272. https://doi.org/10.4236/fns.2018.911090

Received: October 5, 2018

Accepted: November 6, 2018

Published: November 9, 2018

Copyright (c) 2018 by authors and Scientific Research Publishing Inc. This work is licensed under the Creative Commons Attribution International License (CC BY 4.0).

http://creativecommons.org/licenses/by/4.0/

\section{(c) () Open Access}

\begin{abstract}
Fish processing environment is very favorable for the growth of microorganisms and highlights a potential risk associated with microbial hazards. The present study investigated the growth behavior of aerobic bacteria, yeasts and molds, and bacterial pathogens or surrogate (Listeria monocytogenes and Clostridium sporogenes) on thawed and fresh catfish fillets during refrigerated storage $\left(5^{\circ} \mathrm{C}-7^{\circ} \mathrm{C}\right)$. Thawed and fresh fillets were respectively inoculated with L. monocytogenes and C. sporogenes, and packaged in LDPE bags. In uninoculated catfish, the populations of aerobic bacteria, and yeasts and molds increased significantly $(\mathrm{P}<0.05)$ after $24 \mathrm{~h}$ of storage. The acceptable microbial limit was exceeded by aerobic bacteria (7.446 log CFU/g) after 4 days, and yeasts and molds (2.97 log CFU/g) after 3 days of refrigerated storage. Listeria population increased by $1.51 \mathrm{log}$ CFU/g on thawed catfish after 6 days of storage. However, there was no significant increase in growth of $C$. sporogenes vegetative cells on fresh catfish fillets. These results indicated that the microbiological quality of refrigerated thawed catfish would become unacceptable within 3 - 4 days. Our results also implied that environmental pathogens such as L. monocytogenes and Clostridium sp. can survive on catfish fillets for extended periods during refrigerated storage. Proper sanitation and hygienic practices are essential to control microbial hazards during handling and processing of catfish fillets.
\end{abstract}

\section{Keywords}

Microbial Growth, Catfish Fillets, Refrigerated Storage, Listeria monocytogenes, Clostridium sporogenes 


\section{Introduction}

Foodborne illnesses have become a significant global health problem due to the increased consumption of foods contaminated with pathogenic microorganisms or their toxins [1] [2]. Foodborne diseases account for approximately 24,484 illnesses, 5677 hospitalizations, and 122 deaths in the United States in 2017. A 96\% increase in the total number of bacterial infections has occurred in 2017, in comparison with the 2014-2016 average [1]. Fresh fish fillets are considered highly perishable, and both fresh fish and processing environments are potential sources of different foodborne pathogens [3]. Freezing of fish throughout the distribution chain is a common practice to maintain the quality, and extend its storage life [3]. However, with the increase in freeze-thaw cycles during cold storage, the defrosted fish often gets contaminated with spoilage microorganisms, and loses its quality and shelf-life [4], thus becoming a significant concern to the food industry [3] [5].

Recent outbreaks of Listeria monocytogenes with refrigerated foods highlighted a critical food safety issue associated with thawed catfish. Majority of Listeria outbreaks related to processed foods are traced back to the processing environment as the primary source of contamination [6]. Frozen catfish after thawing is commonly sold and stored at refrigeration temperature for several days at supermarkets [2] [6]. L. monocytogenes is a psychrotrophic, ubiquitous foodborne pathogen, and has a wide growth temperature range $\left(2^{\circ} \mathrm{C}-45^{\circ} \mathrm{C}\right)$ [2]. The serotype $4 \mathrm{~b}$ is usually involved in causing human listeriosis in both the United States and Europe [6]. Its abilities to survive and multiply at refrigeration temperatures $\left(2^{\circ} \mathrm{C}-4^{\circ} \mathrm{C}\right)$ and under reduced oxygen levels, increase its survival possibility in vacuum-packaged refrigerated foods [7], thereby posing a potential threat to the food industry [2].

Furthermore, FDA recommends that raw fish stored at refrigerated condition should be packaged in an oxygen-permeable condition [8]. Although reduced oxygen packaging (e.g., vacuum packaging, modified atmosphere packaging) can extend the shelf-life of raw fish by limiting the growth of aerobic spoilage bacteria [9], these products become potential targets for the obligate anaerobe Clostridium botulinum and production of botulinum toxin, without visible signs of spoilage [8]. Therefore, examination of potential growth of anaerobic spore-forming pathogens is essential to examine the risk associated with $C$. botulinum in vacuum-packaged foods [10].

In this study, we have examined the growth of aerobic bacteria, and yeast and molds on thawed catfish fillets stored at refrigerated temperatures for six days. The growth and survival of L. monocytogenes and C. sporogenes on thawed and fresh catfish fillets respectively under different packaging conditions during refrigerated storage was also examined. C. sporogenes is often used as a surrogate bacterium for $C$. botulinum because of similar physiology and phylogeny between the two organisms [11]. The results of our study will highlight the importance of proper sanitary conditions required during thawing and potential food 
safety issues related to the packing of fresh or thawed catfish.

\section{Materials and Methods}

\subsection{Examination of Growth of Aerobic Bacteria, and Yeast and Molds}

The microbial quality of thawed catfish fillets was determined by total aerobic bacterial count, and yeast and mold count using Petrifilms plate method [5]. Frozen raw catfish fillets were purchased from the local retail market and stored frozen at $-20^{\circ} \mathrm{C}$ until use. On the day of the experiment, individually packed frozen fillets were thawed using sterilized distilled water, $27^{\circ} \mathrm{C}$ for about $1 \mathrm{~h}$ until their temperature was about $3^{\circ} \mathrm{C}$ (as measured by a calibrated thermometer). Thawed catfish fillets were cut into $5 \times 7.6 \mathrm{~cm}^{2}$ slices, each weighing about $20 \pm$ $0.3 \mathrm{~g}$ under a vertical flow clean bench. The fillets were aseptically transferred into sterile Low-density polyethylene (LDPE) bags or petri plates, and stored at $5^{\circ} \mathrm{C}$ up to 6 days (Figure 1(a), Figure 1(b)). Microbial analysis (total aerobic, yeast and mold counts) of each of the samples were determined at $0,1,2,3,4,5$ and 6 days. At each sampling time, the fillets from each packaging schemes were placed into sterile stomacher bags, and pummeled vigorously with $180 \mathrm{ml}$ of sterile $0.1 \%(\mathrm{w} / \mathrm{v})$ peptone water (PW; Hardy Diagnostics, CA, USA) using a stomacher (BagMixer ${ }^{\circledR} 400 S$, Interscience, Woburn, MA, USA) for 2 min at a speed of 3 . The homogenate samples were serially diluted 10 -fold with $0.1 \%(\mathrm{w} / \mathrm{v})$ sterile PW. For total aerobic bacterial count, the samples were plated on $3 \mathrm{M}$ Petrifilm $^{\text {rm }}$ Aerobic Count Plates ( 3 M Health Care, MN, USA). After $48 \mathrm{~h}$ of incubation at $35^{\circ} \mathrm{C}$, the positive colonies on the plates were recorded. The yeast and mold counts were determined using $3 \mathrm{M}^{\mathrm{mm}}$ Petrifilm ${ }^{\mathrm{mm}}$ Yeast and Mold Count Plates ( $3 \mathrm{M}$ Health Care, MN, USA) after 3 - 5 days of incubation at $28^{\circ} \mathrm{C}$.

\subsection{Preparation of Bacterial Inoculum}

\subsubsection{Listeria monocytogenes}

Listeria monocytogenes (strain $101 \mathrm{M}$; serotype 4b; isolated at the Food Research

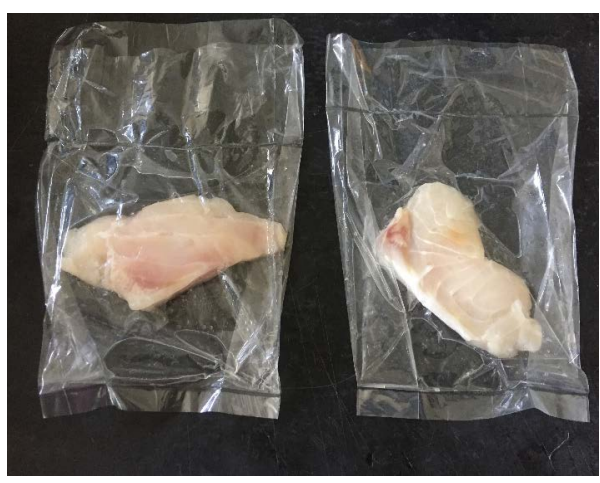

(a)

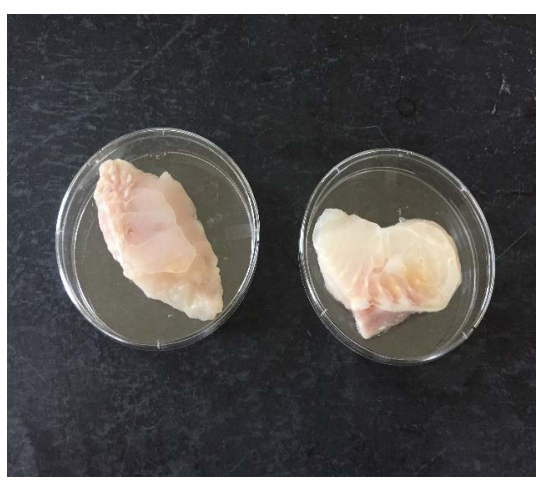

(b)

Figure 1. Packaging conditions used to examine microbial growth on thawed catfish fillets. (a) packed in Low-density polyethylene (LDPE) bags, (b) stored in petri plates (unpacked samples). 
Institute from ground beef) was used in this study. Stock culture of the organism was maintained in Tryptic soy broth with $0.6 \%$ yeast extract (TSBYE; Hardy Diagnostics, CA, USA) with $20 \%$ glycerol in cryovials (Corning INC. NY, USA) at $-20^{\circ} \mathrm{C}$.

Bacterial culture was prepared according to Juck et al. [12] with some modifications. Working culture was prepared by activating the stock strain in two successive passes at $37^{\circ} \mathrm{C}$ for 18 to $24 \mathrm{~h}$ in $10 \mathrm{ml}$ of TSBYE. After the second incubation, a loopful of culture was streaked onto Tryptic soy agar (TSA; Hardy Diagnostics, CA, USA) plate and incubated at $37^{\circ} \mathrm{C}$ for 18 to $24 \mathrm{~h}$. Then a colony was transferred into a $10 \mathrm{ml}$ of TSBYE tube and incubated at $37^{\circ} \mathrm{C}$ for $24 \mathrm{~h}$. The broth culture was combined with $27 \mathrm{ml}$ sterile $0.1 \%$ (w/v) PW and centrifuged for $10 \mathrm{~min}$ at $5000 \times \mathrm{g}$ at $4^{\circ} \mathrm{C}$. Then the supernatant was decanted and the pellet was washed with $36 \mathrm{ml} \mathrm{PW}$ by the same centrifugation process. Finally, the pellet was resuspended in PW to a final volume of $25 \mathrm{ml}$ and used as the inoculum.

\subsubsection{Clostridium sporogenes}

The inoculum of $C$. sporogenes was prepared by the method described by Adhikari et al. [13] with some modifications as well as following instructions on ATCC product sheet. Briefly, $0.1 \mathrm{ml}$ aliquot of the frozen culture of Clostridium sporogenes ATCC 3584 maintained in TSB with 5\% sheep blood (Hardy Diagnostics, CA, USA), was transferred into $10 \mathrm{ml}$ of fresh TSB with $5 \%$ sheep blood, and incubated at $37^{\circ} \mathrm{C}$ for $24 \mathrm{~h}$ under anaerobic conditions. Then one loopful of the broth culture was streaked on the TSA plates containing 5\% sheep blood, and incubated under an anaerobic condition at $37^{\circ} \mathrm{C}$ for $24 \mathrm{~h}$ to form the stock culture plates. A single colony from a stock culture plate was incubated in $10 \mathrm{ml}$ TSB (with 5\% sheep blood) for $24 \mathrm{~h}$ at $37^{\circ} \mathrm{C}$ under anaerobic conditions. As described in the above section, the broth culture was resuspended in sterile PW and centrifuged. Finally, the bacterial inoculum was prepared in PW to a final volume of $25 \mathrm{ml}$.

\subsection{Inoculation and Growth of Listeria monocytogenes and Clostridium sporogenes}

\subsubsection{L. monocytogenes}

Thawed catfish fillets were cut into $20 \pm 0.3 \mathrm{~g}$ pieces $\left(5 \times 7.6 \mathrm{~cm}^{2}\right.$ slice $)$ as described in Section 2.1, and spot inoculated with $0.1 \mathrm{ml}$ of $L$. monocytogenes $\left(1.85 \times 10^{7} \mathrm{CFU} / \mathrm{ml}\right)$. The fillets were allowed to stand for about $2 \mathrm{~min}$ in biosafety hood. Then the samples were kept in LDPE bags or petri plates (unpacked) and stored at refrigerated temperature $\left(5^{\circ} \mathrm{C}\right)$. The whole experiment was done under a vertical flow clean bench. Bacterial count was determined from each sample at every $24 \mathrm{~h}$ from 0 days to 6 days.

The samples were homogenized with $180 \mathrm{ml}$ of sterile PW $(0.1 \%$, w/v) using a lab blender as described in Section 2.1. The homogenate samples were serially diluted 10 -fold with $0.1 \%(w / v)$ sterile PW. As described by Juck et al. [12], Listeria population was enumerated using the spread plating technique on the Lis- 
teria Selective agar base (Oxford formulation; Oxoid ${ }^{\text {Tw }}$, Thermo Fisher Scientific Inc.) containing modified Listeria Selective Supplement (Oxford formulation; Oxoid $^{\mathrm{mm}}$, Thermo Fisher Scientific Inc.). The plates were incubated at $35^{\circ} \mathrm{C}$, and typical Listeria colonies (small to medium size, gray-brown to black) were counted after $48 \mathrm{~h}$ of incubation.

\subsubsection{C. sporogenes}

Fresh catfish fillets were purchased from the local retail market, and were cut into $20 \pm 0.3 \mathrm{~g}$ pieces each $\left(5 \times 7.6 \mathrm{~cm}^{2}\right.$ slice $)$. Each of these pieces was then aseptically kept in separate petri plates, and spot inoculated with $0.1 \mathrm{ml}$ of C. sporogenes $\left(3.7 \times 10^{7} \mathrm{CFU} / \mathrm{ml}\right)$. After inoculation, the samples were placed in LDPE bags which were subjected to two types of packaging treatment: 1) the bags were sealed using vacuum packaging machine (FoodSaver, USA) and 2) the bags were sealed without vacuum. The whole experiment was carried under the vertical flow clean bench. All the samples were incubated at $5^{\circ} \mathrm{C}$, and bacterial counts were determined at every $24 \mathrm{~h}$ from 0 days to 6 days.

As described in Section 2.1, all the fillets samples (from 0 to $6^{\text {th }}$ day) were blended and diluted 10-fold with sterile PW. As described by Adhikari et al. [13], a $0.1 \mathrm{ml}$ from each of dilution was spread plated on Shahidi Ferguson Perfringens (SFP) Agar Base (Becton, Dickinson and Company, USA) with egg yolk enrichment, kanamycin and polymyxin B (Oxoid Ltd., England). The plates were placed in an anaerobic jar (Mitsubishi Gas Chemical America Inc., New York, NY) along with a sachet with oxygen scavenger (Mitsubishi Gas Chemical America Inc., New York, NY) to produce an anaerobic atmosphere. After an incubation of $24 \mathrm{~h}$ at $37^{\circ} \mathrm{C}$, large black colonies of C. sporogenes were enumerated.

\subsection{Statistical Analysis}

Statistical analysis was performed by Microsoft Excel 2007 (Microsoft Inc, Redmond USA) and STATGRAPHICS Plus for Windows Version 3 (Statpoint Technologies, Inc). Significant differences between samples were determined by analysis of variance (ANOVA) and Tukey's comparison test at $\mathrm{P}<0.05$. Results are expressed in Mean \pm Standard Deviation (S.D.) of samples $(n=3)$.

\section{Results and Discussion}

\subsection{Growth of Aerobic Bacteria, Yeast and Molds}

The change in Aerobic Plate Count (APC) of the thawed catfish samples during refrigerated storage is presented in Table 1 . The initial APC (at day 0) of both the samples (LDPE-packed or unpacked) was found to be $4.08 \pm 0.23 \log$ CFU/g, which is in accordance with the results reported by Suvanich and Marshall [14]. The lower initial APC indicated a minimal cross-contamination, which may be because of proper sanitation and handling during thawing [5]. The APC of unpacked samples remained similar up to day 2. However, the counts increased significantly $(\mathrm{P}<0.05)$ after 3 days from $4.75 \pm 0.65 \log \mathrm{CFU} / \mathrm{g}$ (day 3$)$ to $6.59 \pm$ 
$0.24 \log \mathrm{CFU} / \mathrm{g}$ (day 6), signifying an increase in microbial activity at refrigerated temperature. While, in LDPE-packed catfish, the APC increased significantly to $5.38 \pm 0.55 \log \mathrm{CFU} / \mathrm{g}$ within 2 days, which further increased up to $8.76 \pm 0.19$ $\log \mathrm{CFU} / \mathrm{g}$ (day 6), indicating higher microbial activity in packaged conditions.

The maximum limit of APC for acceptable microbiological quality for seafood is $10^{7} \mathrm{CFU} / \mathrm{g}$ [15]. Based upon our results, the APC level exceeded the recommended limit within 4 days for LDPE-packed refrigerated catfish fillets. However, the level remained within limits in unpacked catfish fillets during refrigerated storage. This indicated higher microbial growth in packaged fillets than unpacked ones, under refrigerated conditions. This result is supported by several previous studies, that reported growth of aerobic bacteria in sushi [16], Bighead Carp [17] as well as in meat [18] during refrigerated storage under different packaging conditions, which significantly led to food spoilage.

The change in total yeast and mold counts on the thawed catfish fillets stored at refrigerated temperature is shown in Table 2. The initial level of total yeasts

Table 1. Changes in Aerobic Plate counts (APC) in log CFU/g on thawed catfish fillets packed in LDPE bags and petri plates (unpacked samples) during refrigerated storage $\left(5^{\circ} \mathrm{C}-7^{\circ} \mathrm{C}\right)$. Results in each column not sharing a common superscript value (a-e) differ significantly from each other at $\mathrm{P}<0.05$.

\begin{tabular}{ccc}
\hline \multirow{2}{*}{ Time (days) } & \multicolumn{2}{c}{ Aerobic Plate Count (APC) on catfish fillets (log CFU/g) } \\
\cline { 2 - 3 } & Unpacked & LDPE-packed \\
\hline 0 & $4.08 \pm 0.23^{\mathrm{a}}$ & $4.08 \pm 0.23^{\mathrm{a}}$ \\
1 & $4.09 \pm 0.14^{\mathrm{a}}$ & $3.96 \pm 0.25^{\mathrm{a}}$ \\
2 & $4.18 \pm 0.29^{\mathrm{ab}}$ & $5.38 \pm 0.55^{\mathrm{b}}$ \\
3 & $4.74 \pm 0.64^{\mathrm{ab}}$ & $6.78 \pm 0.36^{\mathrm{c}}$ \\
5 & $4.89 \pm 0.15^{\mathrm{b}}$ & $7.44 \pm 0.89^{\mathrm{cd}}$ \\
6 & $6.14 \pm 0.79^{\mathrm{c}}$ & $8.27 \pm 0.42^{\mathrm{de}}$ \\
& $6.59 \pm 0.23^{\mathrm{c}}$ & $8.76 \pm 0.18^{\mathrm{e}}$ \\
\hline
\end{tabular}

Table 2. Changes in total yeasts and molds counts (log CFU/g) on thawed catfish fillets packed in LDPE bags and petri plates (unpacked samples) during refrigerated storage $\left(5^{\circ} \mathrm{C}-7^{\circ} \mathrm{C}\right)$. Results in each column not sharing a common superscript value (a-f) differ significantly from each other at $\mathrm{P}<0.05$.

\begin{tabular}{ccc}
\hline \multirow{2}{*}{ Time (days) } & \multicolumn{2}{c}{ Total yeast and mold count on catfish fillets (log CFU/g) } \\
\cline { 2 - 3 } & Unpacked & LDPE-packed \\
\hline 0 & $2.22 \pm 0.02^{\mathrm{a}}$ & $2.22 \pm 0.02^{\mathrm{a}}$ \\
1 & $2.68 \pm 0.02^{\mathrm{b}}$ & $2.80 \pm 0.20^{\mathrm{b}}$ \\
2 & $2.69 \pm 0.02^{\mathrm{b}}$ & $2.90 \pm 0.02^{\mathrm{c}}$ \\
3 & $2.91 \pm 0.02^{\mathrm{c}}$ & $2.96 \pm 0.02^{\mathrm{c}}$ \\
4 & $3.84 \pm 0.02^{\mathrm{d}}$ & $3.97 \pm 0.02^{\mathrm{d}}$ \\
5 & $4.28 \pm 0.03^{\mathrm{e}}$ & $4.53 \pm 0.03^{\mathrm{e}}$ \\
6 & $4.46 \pm 0.03^{\mathrm{f}}$ & $4.66 \pm 0.03^{\mathrm{f}}$ \\
\hline
\end{tabular}


and molds was $2.22 \pm 0.02 \log \mathrm{CFU} / \mathrm{g}$ (day 0) which increased to $2.92 \pm 0.03 \log$ CFU/g (unpacked samples) and $2.97 \pm 0.03 \mathrm{log}$ CFU/g (LDPE-packed samples) within day 3. On unpacked samples, the counts increased significantly to $3.84 \pm$ $0.03 \log \mathrm{CFU} / \mathrm{g}$ in day 4, which further increased to $4.28 \pm 0.03 \mathrm{log}$ CFU/g in day 5 and to $4.46 \pm 0.03104 \log \mathrm{CFU} / \mathrm{g}$ in day 6. In LDPE-packed samples, the counts increased significantly to $3.97 \pm 0.03 \log \mathrm{CFU} / \mathrm{g}$ in day $4,4.54 \pm 0.03 \mathrm{log} \mathrm{CFU} / \mathrm{g}$ in day 5 and to $4.67 \pm 0.03 \log$ CFU/g in day 6 . The acceptable limit for yeast and mold count in foods is $<1000 \mathrm{CFU} / \mathrm{g}$ [19]. Our results showed that the yeast and mold counts exceeded this limit after 3 days of storage. Therefore, these results indicated that thawed catfish fillets should not be consumed after 3 days of storage at refrigerated temperature. Increase in yeast and mold counts in fish samples during refrigerated storage have also been previously reported [17], which have also substantiated the results of our study.

Moreover, we observed that both APC, and yeast and mold counts were significantly higher in the LDPE-packed catfish than the unpacked samples. This effect on the microbial growth might be attributed to the low relative humidity $(\mathrm{RH})(51.4 \% \pm 3.28 \%)$ of the refrigerated storage $\left(5^{\circ} \mathrm{C}-7^{\circ} \mathrm{C}\right)$. The fish surfaces often get dehydrated in an environment of about $50 \% \mathrm{RH}$ at any given temperature, resulting in a decrease in the viable microbial count [20]. In our study, the unpacked samples kept in petri plates mimicked the condition of keeping fish samples directly exposed to the medium humidity environment. Therefore, the dry surfaces of fish fillets on the petri plates may have significantly limited the microbial growth. On the other hand, the LDPE bags might have prevented the loss of moisture from the fillet samples during refrigerated storage, and could have contributed to develop moist conditions on the surface, resulting in an increased growth of microorganisms [20]. Furthermore, it was observed that the yeast and mold counts on the fillets were lesser in number than the APC. These results corroborated with findings of Latip et al. [17] with lower levels of yeasts on fish and rarely detectable molds associated with aquatic life. From our present study, we can infer that the shelf life of thawed catfish fillets is limited to 3 days because of the growth of spoilage microorganisms.

\subsection{Growth of L. monocytogenes}

As shown in Table 3, the count of L. monocytogenes increased from 4 log $\mathrm{CFU} / \mathrm{g}$ (0 day) to $4.86 \log \mathrm{CFU} / \mathrm{g}$ and $5.51 \mathrm{log} \mathrm{CFU} / \mathrm{g}$ within 6 days in unpacked and LDPE-packed thawed fillets respectively. There was no significant difference $(\mathrm{P}>0.05)$ in Listeria counts between the LDPE-packed and unpacked catfish samples over the storage period. Refrigerated food products primarily seafood are potential targets for L. monocytogenes contamination [6]. Several studies reported that L. monocytogenes can grow on different refrigerated seafood products during refrigerated storage [7] [21]-[26]. Rajkowski and Sommers [25] reported an increase in L. monocytogenes count on catfish fillets during refrigerated storage. They found that the total population of the pathogen increased by 
Table 3. Survival and growth of L. monocytogenes (log CFU/g) on thawed catfish fillets packed in LDPE bags and petri plates (unpacked samples) stored at refrigerated temperature $\left(5^{\circ} \mathrm{C}-7^{\circ} \mathrm{C}\right)$. Results in each column not sharing a common superscript value (a-f) differ significantly from each other at $\mathrm{P}<0.05$.

\begin{tabular}{ccc}
\hline \multirow{2}{*}{ Time (days) } & \multicolumn{2}{c}{ L. monocytogenes on catfish fillets $(\log$ CFU/g) } \\
\cline { 2 - 3 } & Unpacked & LDPE-packed \\
\hline 0 & $4.00 \pm 0.00^{\mathrm{a}}$ & $4.00 \pm 0.00^{\mathrm{a}}$ \\
2 & $3.34 \pm 0.21^{\mathrm{b}}$ & $3.24 \pm 0.17^{\mathrm{b}}$ \\
3 & $4.01 \pm 0.01^{\mathrm{a}}$ & $4.12 \pm 0.01^{\mathrm{c}}$ \\
4 & $4.20 \pm 0.01^{\mathrm{c}}$ & $4.67 \pm 0.04^{\mathrm{d}}$ \\
5 & $4.49 \pm 0.03^{\mathrm{d}}$ & $5.02 \pm 0.01^{\mathrm{e}}$ \\
6 & $4.54 \pm 0.03^{\mathrm{d}}$ & $5.11 \pm 0.01^{\mathrm{e}}$ \\
\hline
\end{tabular}

$1.4 \log \mathrm{CFU} / \mathrm{g}$ and $2.8 \log \mathrm{CFU} / \mathrm{g}$ after 5 and 10 days of storage respectively. Also in 1998, Fernandes et al. observed a $1.9 \log \mathrm{CFU} / 100 \mathrm{~g}$ increase in L. monocytogenes count in catfish fillets after 15 days of refrigerated storage. At similar storage temperature for 12 days, Liu et al. [24] observed an increase in the bacterial population in tuna meat, by $3.31 \log$ CFU/g. Likewise, Jafari et al. [23] observed that the population of L. monocytogenes increased by $1.65 \mathrm{log} \mathrm{CFU} / \mathrm{g}$ and 2.3 $\log \mathrm{CFU} / \mathrm{g}$ on Huso huso fillets after 4 and 8 days of refrigerated storage respectively.

Rapid growth of Listeria spp in seafoods might be the results of easily available nutrients and the ability of Listeria to grow at refrigerated temperature. The facultatively anerobic nature of $L$. monocytogenes has also allowed this pathogen to grow in different packaging conditions (such as air and vacuum), regardless of the oxygen levels in them [27]. These previous results have therefore, substantiated the results of our study on the survival and growth of L. monocytogenes on both packed and unpacked catfish fillets during refrigerated storage. In addition, an increase in moisture level after thawing might have aided the growth of the pathogen. Therefore, an increase in Listeria count during refrigerated storage indicated that the storage of thawed catfish fillets for a longer period can increase the food safety risk.

Listeria contamination of food products has been generally associated with poor sanitation conditions or handling practices in the food processing plants. Effective cleaning and proper hand washing procedures can minimize the risk of Listeria contamination from the processing environments [28] [29] [30]. Since fish processing environments are favorable for the growth of Listeria [6], suitable processing and storage parameters should be in place to minimize the food safety risk.

\subsection{Growth of $C$. sporogenes Vegetative Cells}

C. sporogenes counts in fresh catfish samples was unaffected over the sampling 
period (0 - 6 days) under both packaging conditions (LDPE bags sealed with vacuum and sealed without vacuum) stored at $5^{\circ} \mathrm{C}$ (Table 4). The optimum growth temperature for C. sporogenes is between $\left(35^{\circ} \mathrm{C}-40^{\circ} \mathrm{C}\right)$ [31]. In our study, we inoculated $C$. sporogenes on catfish fillets and incubated them in an anaerobic chamber at $5^{\circ} \mathrm{C}$, mimicking refrigerated storage conditions. Our results indicated that $C$. sporogenes survived in catfish samples at $5^{\circ} \mathrm{C}$, but the level remained same throughout the storage period. Our results are also in accordance with that of Al-Qadiri et al. [32], which demonstrated that in anaerobic condition the inoculated $C$. perfringens was able to survive on beef samples for 14 days at refrigerated temperature $\left(7^{\circ} \mathrm{C}\right)$ but with a reduction in cell counts. Their results reported that storage temperature is critical for the survival and growth of Clostridium sp. on foods under different packaging conditions. Likewise, Cai et al. [33] reported that storing catfish under abusive temperature conditions will increase the growth of $C$. botulinum and its toxin production. These reports collaborate the findings of the current study that storing vacuum-packed catfish fillets in refrigerated conditions will minimize the growth of C. sporogenes. Furthermore, contamination of foods by Clostridium sp. indicates that the hygienic condition was not maintained properly during the processing, preparation and storage of those food products [34]. Therefore, proper hygiene and sanitation should be maintained during food processing and storage in order to prevent food spoilage by these bacteria.

\section{Conclusion}

Even at refrigerated temperature, the microbiological quality of thawed catfish fillets would deteriorate if stored for extended periods. The APC, and the yeast and mold counts on thawed catfish exceeded the maximum limit recommended by ICMSF for acceptable microbiological quality in seafood, within 4 days and 3 days of refrigerated storage respectively. Based on these results, it can be suggested

Table 4. Survival and growth of $C$. sporogenes (log CFU/g) on fresh catfish fillets with or without vacuum-packed and stored at refrigerated temperature $\left(5^{\circ} \mathrm{C}-7^{\circ} \mathrm{C}\right)$. Results in each column not sharing a common superscript value (a-e) differ significantly from each other at $\mathrm{P}<0.05$. Vacuum $=$ Vacuum packaged; Sealed without vacuum $=$ normally packed in LDPE bags.

\begin{tabular}{ccc}
\hline \multirow{2}{*}{ Time (days) } & \multicolumn{2}{c}{ C. sporogenes on catfish fillets $(\log$ CFU/g) } \\
\cline { 2 - 3 } & Vacuum & Sealed without vacuum \\
\hline $\mathbf{1}$ & $5.56 \pm 0.01^{\mathrm{a}}$ & $5.56 \pm 0.01^{\mathrm{a}}$ \\
$\mathbf{2}$ & $5.38 \pm 0.00^{\mathrm{b}}$ & $5.06 \pm 0.00^{\mathrm{b}}$ \\
$\mathbf{3}$ & $5.09 \pm 0.01^{\mathrm{ce}}$ & $5.22 \pm 0.01^{\mathrm{c}}$ \\
$\mathbf{4}$ & $4.88 \pm 0.07^{\mathrm{c}}$ & $4.76 \pm 0.05^{\mathrm{d}}$ \\
$\mathbf{5}$ & $4.97 \pm 0.09^{\mathrm{c}}$ & $4.93 \pm 0.08^{\mathrm{d}}$ \\
$\mathbf{6}$ & $4.58 \pm 0.03^{\mathrm{d}}$ & $5.14 \pm 0.00^{\mathrm{bc}}$ \\
\end{tabular}


that the shelf life of refrigerated thawed catfish may be limited to 3 days due to the growth of spoilage microorganisms. In addition, once contaminated, L. monocytogenes and $C$. sporogenes can survive on the fish fillets for extended periods at refrigerated temperature. Proper packaging, storage conditions and following sanitation and hygienic practices are important to minimize food safety risks and increase the shelf-life of catfish fillets.

\section{Acknowledgements}

This work was supported by the USDA Foreign Agricultural Service (FAS), Agreement No. BF-CR-16-022. The authors thank LSU AgCenter International Program for their help and support.

\section{Conflicts of Interest}

The authors declare no conflicts of interest regarding the publication of this paper.

\section{References}

[1] Centers for Disease Control and Prevention (CDC). (2017) Foodborne Diseases Active Surveillance Network (FoodNet): FoodNet 2017 Preliminary Data. https://www.cdc.gov/foodnet/reports/prelim-data-intro-2017.html

[2] Gandhi, M. and Chikindas, M.L. (2007) Listeria: A Foodborne Pathogen that Knows How to Survive. International Journal of Food Microbiology, 113, 1-15. https://doi.org/10.1016/j.ijfoodmicro.2006.07.008

[3] Pao, S., Ettinger, M., Khalid, M., Reid, A. and Nerrie, B. (2008) Microbial Quality of Raw Aquacultured Fish Fillets Procured from Internet and Local Retail Markets. Journal of Food Protection, 71, 1544-1549. https://doi.org/10.4315/0362-028X-71.8.1544

[4] Nirmal, N.P. and Benjakul, S. (2010) Effect of Catechin and Ferulic Acid on Melanosis and Quality of Pacific White Shrimp Subjected to Prior Freeze-Thawing during Refrigerated Storage. Food Control, 21, 1263-1271. https://doi.org/10.1016/j.foodcont.2010.02.015

[5] Suvanich, V., Marshall, D. and Jahncke, M. (2000) Microbiological and Color Quality Changes of Channel Catfish Frame Mince during Chilled and Frozen Storage. Journal of Food Science, 65, 151-154. https://doi.org/10.1111/j.1365-2621.2000.tb15971.x

[6] Jami, M., Ghanbari, M., Zunabovic, M., Domig, K.J. and Kneifel, W. (2014) Listeria monocytogenes in Aquatic Food Products-A Review. Comprehensive Reviews in Food Science and Food Safety, 13, 798-813. https://doi.org/10.1111/1541-4337.12092

[7] Harrison, M.A., Huang, Y.-W., Chao, C.-H. and Shineman, T. (1991) Fate of Listeria monocytogenes on Packaged, Refrigerated, and Frozen Seafood. Journal of Food Protection, 54, 524-527. https://doi.org/10.4315/0362-028X-54.7.524

[8] Food and Drug Administration. (2011) Fish and Fishery Products Hazards and Controls Guidance. Fourth Edition, April 2011.

[9] DeWitt, C.A.M. and Oliveira, A. (2016) Modified Atmosphere Systems and Shelf Life Extension of Fish and Fishery Products. Foods, 5, 48. 
https://doi.org/10.3390/foods5030048

[10] Hernández-Macedo, M.L., Barancelli, G.V. and Contreras-Castillo, C.J. (2011) Microbial Deterioration of Vacuum-Packaged Chilled Beef Cuts and Techniques for Microbiota Detection and Characterization: A Review. Brazilian Journal of Microbiology, 42, 1-11. https://doi.org/10.1590/S1517-83822011000100001

[11] Wang, S., Brunt, J., Peck, M.W., Setlow, P. and Li, Y.-Q. (2017) Analysis of the Germination of Individual Clostridium sporogenes Spores with and without Germinant Receptors and Cortex-Lytic Enzymes. Frontiers in Microbiology, 8, 2047. https://doi.org/10.3389/fmicb.2017.02047

[12] Juck, G., Neetoo, H. and Chen, H. (2010) Application of an Active Alginate Coating to Control the Growth of Listeria monocytogenes on Poached and Deli Turkey Products. International Journal of Food Microbiology, 142, 302-308. https://doi.org/10.1016/j.ijfoodmicro.2010.07.006

[13] Adhikari, A., Yemmireddy, V.K., Costello, M.J., Gray, P.M., Salvadalena, R., Rasco, B. and Killinger, K. (2018) Effect of Storage Time and Temperature on the Viability of E. coli O157:H7, Salmonella spp., Listeria innocua, Staphylococcus aureus, and Clostridium sporogenes Vegetative Cells and Spores in Vacuum-Packed Canned Pasteurized Milk Cheese. International Journal of Food Microbiology, 286, 148-154. https://doi.org/10.1016/j.ijfoodmicro.2018.07.027

[14] Suvanich, V. and Marshall, D.L. (1998) Influence of Storage Time and Temperature on Quality of Catfish (Ictalurus punctatus) Frames. Journal of Aquatic Food Product Technology, 7, 61-74. https://doi.org/10.1300/J030v07n01_05

[15] International Commission for the Microbiological Specifications for Foods (ICMSF). (2011) Microorganisms in Foods 8: Use of Data for Assessing Process Control and Product Acceptance. Springer, New York.

[16] Hoel, S., Jakobsen, A.N. and Vadstein, O. (2017) Effects of Storage Temperature on Bacterial Growth Rates and Community Structure in Fresh Retail Sushi. Journal of Applied Microbiology, 123, 698-709. https://doi.org/10.1111/jam.13527

[17] Latip, L.D., Zzaman, W. and Yang, T.A. (2013) Effect of Chilled-Frozen Storage on the Physico-Chemical, Microbial and Sensory Quality of Farmed Bighead Carp (Hypophthalmichthys nobilis). Journal of Fisheries and Aquatic Science, 8, 686-696. https://doi.org/10.3923/jfas.2013.686.696

[18] Ercolini, D., Russo, F., Torrieri, E., Masi, P. and Villani, F. (2006) Changes in the Spoilage-Related Microbiota of Beef during Refrigerated Storage under Different Packaging Conditions. Applied and Environmental Microbiology, 72, 4663-4671. https://doi.org/10.1128/AEM.00468-06

[19] (2017) Microbiological Specifications for Foods: Developing Specifications and Testing Options for Out of Specification Results.

http://www.wifoodprotection.org/docs/presentations/jun17/LedenbachWAFPPrese ntationOnMicroSpecs.pdf

[20] Stansby, M.E., Pottinger, S.R. and Miyauchi, D.T. (1956) Refrigeration of Fish-Part Three. Factors to Be Considered in the Freezing and Cold Storage of Fishery Products. NOAA National Marine Fisheries Service Scientific Publications Office. https://spo.nmfs.noaa.gov/sites/default/files/legacy-pdfs/leaflet429.pdf

[21] Farber, J. (1991) Listeria monocytogenes in Fish Products. Journal of Food Protection, 54, 922-924. https://doi.org/10.4315/0362-028X-54.12.922

[22] Fernandes, C.F., Flick, G.J. and Thomas, T.B. (1998) Growth of Inoculated Psychrotrophic Pathogens on Refrigerated Fillets of Aquacultured Rainbow Trout and Channel Catfish. Journal of Food Protection, 61, 313-317. 
https://doi.org/10.4315/0362-028X-61.3.313

[23] Jafari, A., Jafarpour, A. and Safari, R. (2017) Influence of Chitosan Nanocomposite and Rosemary (Rosmarinus officinalis L.) Extract Coating on Quality of Huso huso Fillet Inoculated with Listeria monocytogenes during Refrigerated Storage. Journal of Aquatic Food Product Technology, 26, 675-685. https://doi.org/10.1080/10498850.2016.1266427

[24] Liu, C., Mou, J. and Su, Y.-C. (2016) Behavior of Salmonella and Listeria monocytogenes in Raw Yellowfin Tuna during Cold Storage. Foods, 5, 16. https://doi.org/10.3390/foods5010016

[25] Rajkowski, K.T. and Sommers, C. (2012) Effect of Trisodium Phosphate or Water Dip on the Survival of Salmonella and Listeria monocytogenes Inoculated Catfish before and after Freezing. Journal of Aquatic Food Product Technology, 21, 39-47. https://doi.org/10.1080/10498850.2011.579706

[26] Altuntas, E.G., Kocan, D., Cosansu, S., Ayhan, K., Juneja, V.K. and Materon, L. (2012) Antibiotic and Bacteriocin Sensitivity of Listeria monocytogenes Strains Isolated from Different Foods. Food and Nutrition Sciences, 3, 363-368. https://doi.org/10.4236/fns.2012.33052

[27] Rutherford, T.J., Marshall, D.L., Andrews, L.S., Coggins, P.C., Schilling, M.W. and Gerard, P. (2007) Combined Effect of Packaging Atmosphere and Storage Temperature on Growth of Listeria monocytogenes on Ready-to-Eat Shrimp. Food Microbiology, 24, 703-710. https://doi.org/10.1016/j.fm.2007.03.011

[28] Hwang, C.-A., Sheen, S. and Juneja, V. (2011) Effects of Sodium Lactate on the Survival of Listeria monocytogenes, Escherichia Coli O157:H7, and Salmonella spp. in Cooked Ham at Refrigerated and Abuse Temperatures. Food and Nutrition Sciences, 2, 464-470. https://doi.org/10.4236/fns.2011.25066

[29] Wong, W.C., Pui, C.F., Chilek, T.Z.T., Noorlis, A., Tang, J.Y.H., Nakaguchi, Y., Nishibuchi, M. and Radu, S. (2011) Survival of Listeria monocytogenes during Frying of Chicken Burger Patties. Food and Nutrition Sciences, 2, 471-475. https://doi.org/10.4236/fns.2011.25067

[30] Barman, S., Ghosh, R. and Mandal, N.C. (2014) Use of Bacteriocin Producing Lactococcus lactis subsp. lactis LABW4 to Prevent Listeria monocytogenes Induced Spoilage of Meat. Food and Nutrition Sciences, 5, 2115-2123. https://doi.org/10.4236/fns.2014.522224

[31] Simjee, S. (2007) Foodborne Diseases. Humana Press, Totowa. https://doi.org/10.1007/978-1-59745-501-5

[32] Al-Qadiri, H., Sablani, S.S., Ovissipour, M., Al-Alami, N., Govindan, B. and Rasco, B. (2015) Effect of Oxygen Stress on Growth and Survival of Clostridium perfringens, Campylobacter jejuni, and Listeria monocytogenes under Different Storage Conditions. Journal of Food Protection, 78, 691-697. https://doi.org/10.4315/0362-028X.JFP-14-427

[33] Cai, P., Harrison, M.A., Huang, Y.-W. and Silva, J.L. (1997) Toxin Production by Clostridium botulinum Type E in Packaged Channel Catfish. Journal of Food Protection, 60, 1358-1363. https://doi.org/10.4315/0362-028X-60.11.1358

[34] Chhetri, V.S. and Karki, T.B. (2014) Occurrence of Clostridium perfringes in Raw Meat, Poultry and Meat Spices and Effect of Sodium Chloride and Reduced pH on the Outgrowth of Their Spores. Asian Journal of Microbiology, Biotechnology \& Environmental Sciences, 14, 885-890. 